\title{
Response of rice (Oryza sativa L.) productivity and nutrient uptake to nitrogen and boron fertilization in Typic Ustifluvents soil
}

\author{
Abinaya $\mathbf{M}$. \\ Department of Soil Science and Agricultural Chemistry, Faculty of Agriculture, Annamalai \\ University, Annamalainagar-608002 (Tamil Nadu), India

\section{R. Manivannan*} \\ Department of Soil Science and Agricultural Chemistry, Faculty of Agriculture, Annamalai \\ University, Annamalainagar-608002 (Tamil Nadu), India

\section{M.V. Sriramachandrasekharan} \\ Department of Soil Science and Agricultural Chemistry, Faculty of Agriculture, Annamalai \\ University, Annamalainagar-608002 (Tamil Nadu), India

\section{P. Senthilvalavan} \\ Department of Soil Science and Agricultural Chemistry, Faculty of Agriculture, Annamalai \\ University, Annamalainagar-608002 (Tamil Nadu), India

\section{S. Kalaisudarson} \\ Department of Agronomy, Faculty of Agriculture, Annamalai University, Annamalainagar - \\ 608002 (Tamil Nadu), India

\section{Ravikumar} \\ Department of Agronomy, Faculty of Agriculture, Annamalai University, Annamalainagar- \\ 608002 (Tamil Nadu), India \\ ${ }^{*}$ Corresponding author. Email: rengamanivannan@gmail.com
}

\section{How to Cite}

Abinaya, M. et al. (2021). Response of rice (Oryza sativa L.) productivity and nutrient uptake to nitrogen and boron fertilization in Typic Ustifluvents soil. Journal of Applied and Natural Science, 13(4), 1372 - 1377. https://doi.org/10.31018/jans.v13i4.3090

\begin{abstract}
Nitrogen and boron are necessary for the metabolic activities of rice for its growth. With this perspective, a field experiment was conducted in farmer's field during 2020 at Kuttalam, Mayladuthurai district, Tamilnadu in sandy clay loam(Padugai Series TypicUstifluvents) to predict the response of rice (Oryza sativa) to different levels of nitrogen $(\mathrm{N})$ and boron (B) application. The treatments consisted of Factor A- Nitrogen levels, 0, 75, 150, $225 \mathrm{~kg} \mathrm{ha}^{-1}$ and Factor B- Boron levels $0,1.5,3.0 \mathrm{~kg} \mathrm{ha}^{-1}$. Fifteen treatments were conducted in a Factorial randomised block (FRBD) design with three replications. The test crop was rice with a variety ADT 46. Concerning nitrogen alone, the highest grain $\left(5344 \mathrm{~kg} \mathrm{ha}^{-1}\right)$ and straw yield was recorded in $\mathrm{N}_{3}\left(225 \mathrm{~kg} \mathrm{ha}^{-1}\right)$. Among the boron levels tested, the highest grain $\left(4695 \mathrm{~kg} \mathrm{ha}^{-1}\right)$ and straw yield $\left(6509 \mathrm{~kg} \mathrm{ha}^{-1}\right)$ was registered in $\mathrm{B}_{1}\left(1.5 \mathrm{~kg} \mathrm{ha}^{-1}\right)$ in rice. The highest total nutrient uptake viz., $\mathrm{N}\left(88.2 \mathrm{~kg} \mathrm{ha}^{-1}\right), \mathrm{P}\left(30.5 \mathrm{~kg} \mathrm{ha}^{-1}\right), \mathrm{K}\left(105.0 \mathrm{~kg} \mathrm{ha}^{-1}\right)$ and $\mathrm{B}\left(172 \mathrm{mg} \mathrm{kg}^{-1}\right)$ were recorded in $\mathrm{N}_{3} \mathrm{~B}_{1}$. Among the $\mathrm{N}$ alone, the highest total nutrient uptake viz., $\mathrm{N}\left(78.1 \mathrm{~kg} \mathrm{ha}^{-1}, \mathrm{P}\left(26.3 \mathrm{~kg} \mathrm{ha}^{-1}\right), \mathrm{K}\left(95.8 \mathrm{~kg} \mathrm{ha}^{-1}\right)\right.$ and $\mathrm{B}(156.6$ $\left.\mathrm{mg} \mathrm{kg}^{-1}\right)$ in $\mathrm{N}_{3}$. Concerning $B$ alone, the highest nutrient uptake viz., $\mathrm{N}\left(60.5, \mathrm{~kg} \mathrm{ha}^{-1}\right), \mathrm{P}\left(17.8 \mathrm{~kg} \mathrm{ha}^{-1}\right) \mathrm{K}\left(74.9 \mathrm{~kg} \mathrm{ha}^{-1}\right)$ and $B$ $\left(112.1 \mathrm{mg} \mathrm{kg}^{-1}\right)$ were registered in $B_{1}$ over other $B$ levels. The highest grain $\left(5631 \mathrm{~kg} \mathrm{ha}^{-1}\right)$ was recorded in $\mathrm{N}_{3} \mathrm{~B}_{1}\left(225 \mathrm{~kg} \mathrm{~N} \mathrm{ha}^{-1}\right.$ and $1.5 \mathrm{~kg} \mathrm{~B} \mathrm{ha}^{-1}$ ) than other interactions. The study concluded that applying nitrogen and boron is required to achieve the maximum yield of rice in sandy clay loam soil.
\end{abstract}

Keywords: Boron, Grain, Nitrogen, Rice, Straw, Uptake, Yield

\section{INTRODUCTION}

Rice (Oryza sativa L.) is a staple food for more than half of the world's population. Its production worldwide is 510.6 million tons (FAO, 2018). In India, rice is grown in an area of about $44.1 \mathrm{~m}$ ha with a production of 106.7 million tonnes with a productivity of $2.42 \mathrm{t} \mathrm{ha}^{-1}$
(Ramulu et al. 2020). Tamil Nadu occupies third position in rice productivity in India out of the gross cropped area (58.97 $\mathrm{L}$ ha) of the state, paddy alone cultivated in $17.75 \mathrm{~L}$ ha $(31 \%)$ with the annual production(2019-20) of 120 Lakh tonnes(Amarendra Acharya et al. 2020).Nitrogen is important for the protein building, components of aminoacids, nucleic acids and chloro- 
phyll (Jiban Shrestha et al. 2020). Proper N fertilization can improve productivity and profitability as well as reduce adverse environmental impacts(Juan Hirzel and Francisco, 2013). The precise $\mathrm{N}$ application favours the rice growth and yield and reduces the $\mathrm{N}$ losses.Application of $\mathrm{N}$ fertilizer, whether higher or lower, affects the yield and nutrient uptake of rice to higher, hence proper nitrogen levels are important Manzoor et al. 2006). The single nutrient approach causes severe micronutrient deficiencies in soils which retards the crop productivity (Behera et al. 2018). The increased demand forfood grain production has led to continuous depletion of soil micronutrient fertility. Due to poor nutrient use efficiency, there will be anincrease in boron deficiencies in many parts of the country (Singh and Goswami, 2014). Boron is important for the formation of new meristematic cells in rice (Agrinfobank, 2019). Increased photosynthesis due to boron enhances the metabolic activities of cells, activates the synthesis of tryptophan which is responsible for rice growth (Muhammad Asif and Maqsood, 2015). Boron influence the absorption of $\mathrm{N}, \mathrm{P}, \mathrm{K}$ and its deficiency changed the equilibrium of optimum of those three macronutrients (Abbas et al. 2013). Due to B deficiency in soils, rice yield grown in Tamil Nadu is generally low despite the application of a recommended dose of N, P, K and $\mathrm{Zn}$ fertilisers (Gazala Nazir et al. 2014). With this background, the present investigation was carried out to study the effect of different levels of $\mathrm{N}$ and $\mathrm{B}$ on productivity and nutrient uptake in rice (Oryza sativa $L$.).

\section{MATERIALS AND METHODS}

The field experiment was conducted in the farmer's field at Kuttalam, Tamil Nadu, during 2020 in sandy clay loam(Padugai Series- TypicUstifluvents) in samba season to assess the nitrogen and boron nutrition on yield and nutrient uptake in rice (O. sativa). The treatments consisted of Factor A- $\mathrm{N}_{0}$ - no nitrogen, $\mathrm{N}_{1}-75 \mathrm{~kg} \mathrm{ha}^{-1}$, $\mathrm{N}_{2}-150 \mathrm{~kg} \mathrm{ha}^{-1}, \mathrm{~N}_{3}-225 \mathrm{~kg} \mathrm{ha}^{-1}, \mathrm{~N}_{4}-300 \mathrm{~kg} \mathrm{ha}^{-1}$. Factor B- $B_{0}-$ no boron, $B_{1}-1.5 \mathrm{~kg} \mathrm{ha}^{-1}, B_{2}-3.0 \mathrm{~kg} \mathrm{ha}^{-1}$. Totally fifteen treatment combinations were replicated thrice.The experimental soil was sandy clay loam (TypicUstifluvents) with $\mathrm{pH}(6.9)$, EC (0.17), available nitrogen $\left(228.4 \mathrm{~kg} \mathrm{ha}^{-1}\right)$, available phosphorus $(14.3 \mathrm{~kg}$ $\left.\mathrm{ha}^{-1}\right)$, available potassium $\left(270.5 \mathrm{~kg} \mathrm{ha}^{-1}\right)$ and available boron $\left(0.31 \mathrm{mg} \mathrm{kg}^{-1}\right)$. The experiment was laid out in a factorial randomized block design. A medium duration rice variety cv. ADT 46 was used as a test crop. The experimental site was puddled thrice to bring satisfactory tilth. After levelling, the plots were laid out as per the specification of plot size $\left(5 \times 4 \mathrm{~m}^{2}\right)$. Totally 45 plots, were raised and the bunds were strengthened in between replication to prevent seepage of water and nutrients from one plot to another. The recommended dose of 150: $50: 50 \mathrm{~N}, \mathrm{P}_{2} \mathrm{O}_{5}$ and $\mathrm{K}_{2} \mathrm{O}$ ha $^{-1}$ were followed for fertilizer application through urea, superphosphate and muriate of potash. Zinc(zinc sulphate) was applied@ 25 $\mathrm{kg} \mathrm{ha}^{-1}$ as basal dose. Boron was applied through sodium tetraborate or borax $\left(\mathrm{Na}_{2} \mathrm{~B}_{4} \mathrm{O}_{7}\right)$. All the plots received uniform doses of phosphorus $\left(50 \mathrm{~kg} \mathrm{ha}^{-1}\right)$, potassium $\left(50 \mathrm{~kg} \mathrm{ha}^{-1}\right)$ and zinc sulphate $\left(25 \mathrm{~kg} \mathrm{ha}^{-1}\right)$. The spacing adopted was $15 \times 10 \mathrm{~cm}$ and gap-filling was done at 7 DAT. The entire dose of $\mathrm{P}_{2} \mathrm{O}_{5}$ was applied basally before transplanting. Nitrogen and potassium were applied in two split doses. The water level was maintained upto $2.5 \mathrm{~cm}$ uniformly throughout the field trial. The crop was harvested after attaining physiological maturity. The grains were separated by threshing from each plot. The grain and straw yield was computed and expressed as $\mathrm{kg} \mathrm{ha}^{-1}$. The nutrient uptake in grain and straw were computed by multiplying nutrient concentration in grain and straw with grain and straw yield respectively in rice(O.sativa) and expressed as $\mathrm{kg} \mathrm{ha}^{-1}$.

\section{RESULTS AND DISCUSSION}

\section{Rice yield}

Application of nitrogen or boron alone or both significantly $(p=0.05)$ increased the grain and straw yield over control (Table 1,2). The highest grain and straw yield were recorded in combined treatments than individual application. Application of nitrogen and boron $\mathrm{N}_{3} \mathrm{~B}_{1}(225$ $\mathrm{kg} \mathrm{N} \mathrm{ha}^{-1}$ and $\left.1.5 \mathrm{~kg} \mathrm{~B} \mathrm{ha}^{-1}\right)$ recorded the highest grain $\left(5631 \mathrm{~kg} \mathrm{ha}^{-1}\right)$ and straw yield $\left(7637 \mathrm{~kg} \mathrm{ha}^{-1}\right)$, which was significantly superior over other interactions. The best treatment caused a per cent increase in grain(53.9) and straw yield(45.8) over control. The increase in the grain yield may be due to the combined effects of nitrogen and boron exerted a beneficial effect on chlorophyll content in the leaves, which might enhance photosynthetic activity and increase dry matter production in the plant, thus increased rice productivity was realized in the experiment. These results corroborate those of Chanchal et al. (2020) for rice var. ADT 46 with the application of nitrogen and boron application. Concerning nitrogen levels, the highest grain(5344) and straw yield (7304) were recorded in $\mathrm{N}_{3}\left(225 \mathrm{~kg} \mathrm{ha}^{-1}\right)$, which was significantly superior over other $\mathrm{N}$ levels. The grain and straw yield increased up to $\mathrm{N}_{3}$ and declined in $\mathrm{N}_{4}$ $\left(300 \mathrm{~kg} \mathrm{ha}^{-1}\right)$. The lowest yield was recorded in $\mathrm{N}_{0}$. The yield declined at higher doses of $\mathrm{N}$ may be due to taller crop growth which enhanced crop lodging during the grain filling stage resulted in higher spikelet sterility. The results are in line with Bandita Jena and Nayak (2016), who reported that excess $\mathrm{N}$ application might have reduced the carbohydrate content resulting in abnormal development of pollen grains in rice. Further increase of $\mathrm{N}$ has slowly decreased the yield due to 
Abinaya, M. et al. / J. Appl. \& Nat. Sci. 13(4), 1372 - 1377 (2021)

Table 1. Effect of nitrogen and boron on grain and straw yield $(\mathrm{kg} / \mathrm{ha})$ in rice (O. sativa)

\begin{tabular}{|c|c|c|c|c|}
\hline Treatments & Grain yield (kg/ha) & $\begin{array}{l}\text { Percent increase } \\
\text { over control }\end{array}$ & $\begin{array}{l}\text { Straw yield } \\
\text { (kg/ha) }\end{array}$ & $\begin{array}{l}\text { Percent increase } \\
\text { over control }\end{array}$ \\
\hline \multicolumn{5}{|c|}{ N levels(kg/ha) } \\
\hline $\mathrm{N}_{0}-0$ & 3749 & 1.00 & 5288 & 0.19 \\
\hline$N_{1}-75$ & 3965 & 6.58 & 5704 & 6.83 \\
\hline $\mathrm{N}_{2}-150$ & 4404 & 20.42 & 6227 & 18.73 \\
\hline $\mathrm{N}_{3}-225$ & 5344 & 46.10 & 7304 & 39.51 \\
\hline $\mathrm{N}_{4}-300$ & 4902 & 34.03 & 6757 & 29.04 \\
\hline C.D @ 5\% & 45.3 & - & 50.6 & --- \\
\hline \multicolumn{5}{|c|}{ B levels(kg/ha) } \\
\hline $\mathrm{B}_{0}-0$ & 4332 & 17.90 & 6098 & 15.71 \\
\hline $\mathrm{B}_{1}-1.5$ & 4695 & 27.55 & 6509 & 23.97 \\
\hline $\mathrm{B}_{2}-3.0$ & 4393 & 19.42 & 6162 & 16.91 \\
\hline C.D @5\% & 35.1 & -- & 39.2 & ---- \\
\hline
\end{tabular}

Table 2. Interaction effect of nitrogen and boron on grain and straw yield $(\mathrm{kg} / \mathrm{ha})$ in rice (O. sativa)

\begin{tabular}{lllll}
\hline Treatments & Grain yield (kg/ha) & $\begin{array}{l}\text { Per cent increase } \\
\text { over control }\end{array}$ & Straw yield (kg/ha) & $\begin{array}{l}\text { Per cent increase } \\
\text { over control }\end{array}$ \\
\hline $\mathrm{N}_{0} \mathrm{~B}_{0}$ & 3656 & --- & 5234 & --- \\
$\mathrm{N}_{1} \mathrm{~B}_{0}$ & 3860 & 2.82 & 5517 & 2.20 \\
$\mathrm{~N}_{2} \mathrm{~B}_{0}$ & 4201 & 14.88 & 6056 & 15.03 \\
$\mathrm{~N}_{3} \mathrm{~B}_{0}$ & 5178 & 41.56 & 7103 & 35.68 \\
$\mathrm{~N}_{4} \mathrm{~B}_{0}$ & 4763 & 30.23 & 6578 & 25.63 \\
$\mathrm{~N}_{0} \mathrm{~B}_{1}$ & 3829 & 0.72 & 5348 & 0.41 \\
$\mathrm{~N}_{1} \mathrm{~B}_{1}$ & 4147 & 13.36 & 5979 & 14.18 \\
$\mathrm{~N}_{2} \mathrm{~B}_{1}$ & 4726 & 29.23 & 6536 & 24.83 \\
$\mathrm{~N}_{3} \mathrm{~B}_{1}$ & 5631 & 53.93 & 7637 & 45.83 \\
$\mathrm{~N}_{4} \mathrm{~B}_{1}$ & 5140 & 40.53 & 7048 & 34.60 \\
$\mathrm{~N}_{4} \mathrm{~B}_{2}$ & 3762 & 2.28 & 5283 & 0.17 \\
$\mathrm{~N}_{1} \mathrm{~B}_{2}$ & 3887 & 3.55 & 5617 & 4.10 \\
$\mathrm{~N}_{2} \mathrm{~B}_{2}$ & 4286 & 17.16 & 6099 & 16.33 \\
$\mathrm{~N}_{3} \mathrm{~B}_{2}$ & 5223 & 42.80 & 7173 & 37.03 \\
$\mathrm{~N}_{4} \mathrm{~B}_{2}$ & 4804 & 31.34 & 6643 & 26.90 \\
$\mathrm{C} . \mathrm{D} @ 5 \%$ & 78.4 & ---- & 87.6 & --
\end{tabular}

excessive plant growth and crop lodging, which resulted in a number of non-bearing tillers/hills in rice (Jahanet al. 2014). The higher grain yield with $225 \mathrm{~kg} /$ ha might be owing to better $\mathrm{N}$ uptake, leading to a higher number of panicles and panicle length, resulting in higher grain yield. These results corroborate the findings of Salam et al.(2004), who reported that the application of $180 \mathrm{~kg} \mathrm{~N} / \mathrm{ha}$ increased the grain yield due to higher dry matter production and filled grains/panicle in rice.

Among the boron levels, the highest grain(4695 $\mathrm{kg} \mathrm{ha-}$ $\left.{ }^{1}\right)$ and straw yield $\left(6509 \mathrm{~kg} \mathrm{ha}^{-1}\right)$ was registered in $B_{1}$, significantly superior over other boron levels. The grain and straw yield increased upto $B_{1}\left(1.5 \mathrm{~kg} \mathrm{ha}^{-1}\right)$ and declined in $B_{2}\left(3.0 \mathrm{~kg} \mathrm{ha}^{-1}\right)$. The lowest yield was recorded in $B_{0}$. The increase in the grain yield might be due to the importance of $B$ in reproductive growth, which is responsible for panicle formation and retards the panicle sterility in rice (Rehman et al., 2012). The lesser grain yield in the control plot might be due to reduced pollen sterility of rice and poor grain filling(Rashid et al. 2004; Jana et al. 2005). The increased grain and straw yield may be due to the role of boron in sugar transport, flower production, retention, pollen tube elongation and germination and translocation of carbohydrates(Ahamad et al. 2009).

\section{Nutrient uptake}

Application of nitrogen or boron alone or both significantly increased the nutrients uptake (N, P, K, B) over 
Table 3. Effect of nitrogen and boron on total nutrients uptake in rice (O.sativa)

\begin{tabular}{lllll}
\hline Treatments & $\begin{array}{l}\text { Total } \mathbf{N} \text { uptake } \\
(\mathbf{k g} / \mathbf{h a})\end{array}$ & $\begin{array}{l}\text { Total } \mathbf{P} \text { uptake } \\
(\mathbf{k g} / \mathbf{h a})\end{array}$ & $\begin{array}{l}\text { Total K uptake } \\
\mathbf{( k g / h a )}\end{array}$ & $\begin{array}{l}\text { Total B uptake } \\
\mathbf{( g / h a )}\end{array}$ \\
\hline $\mathbf{N}$ levels (kg/ha) & & & & \\
\hline $\mathrm{N}_{0}-0$ & 36.4 & 6.2 & 46.9 & 52.7 \\
$\mathrm{~N}_{1}-75$ & 41.8 & 8.7 & 52.9 & 67.1 \\
$\mathrm{~N}_{2}-150$ & 51.6 & 13.7 & 66.0 & 93.5 \\
$\mathrm{~N}_{3}-225$ & 78.1 & 26.3 & 95.8 & 156.6 \\
$\mathrm{~N}_{4}-300$ & 64.2 & 19.6 & 80.5 & 120.5 \\
C.D @ 5\% & 1.1 & 0.6 & 3.0 & 6.8 \\
\hline B levels (kg/ha) & & & & \\
\hline $\mathrm{B}_{0}-0$ & 51.0 & 13.2 & 64.6 & 112.1 \\
$\mathrm{~B}_{1}-1.5$ & 60.5 & 17.8 & 74.9 & 93.5 \\
$\mathrm{~B}_{2}-3.0$ & 51.8 & 13.7 & 65.7 & 12.0 \\
C.D @5\% & 0.8 & 0.8 & 5.3 & \\
\hline
\end{tabular}

Table 4. Interaction effect of nitrogen and boron on total nutrients uptake in rice (O. sativa)

\begin{tabular}{lllll}
\hline Treatments & $\begin{array}{l}\text { Total } \mathbf{N} \text { uptake } \\
(\mathbf{k g} / \mathbf{h a})\end{array}$ & $\begin{array}{l}\text { Total } \mathbf{P} \text { uptake } \\
\mathbf{( k g / h a )}\end{array}$ & $\begin{array}{l}\text { Total } \mathbf{K} \text { uptake } \\
\mathbf{( k g / h a )}\end{array}$ & $\begin{array}{l}\text { Total } \mathbf{B} \text { uptake } \\
(\mathbf{g} / \mathbf{h a})\end{array}$ \\
\hline $\mathrm{N}_{0} \mathrm{~B}_{0}$ & 35.4 & 5.7 & 46.0 & 51.4 \\
$\mathrm{~N}_{1} \mathrm{~B}_{0}$ & 38.8 & 7.1 & 49.3 & 58.3 \\
$\mathrm{~N}_{2} \mathrm{~B}_{0}$ & 48.1 & 11.9 & 61.9 & 84.2 \\
$\mathrm{~N}_{3} \mathrm{~B}_{0}$ & 72.7 & 24.0 & 90.3 & 145.2 \\
$\mathrm{~N}_{4} \mathrm{~B}_{0}$ & 59.9 & 17.6 & 75.5 & 104.2 \\
$\mathrm{~N}_{0} \mathrm{~B}_{1}$ & 37.5 & 6.6 & 47.4 & 55.3 \\
$\mathrm{~N}_{1} \mathrm{~B}_{1}$ & 47.2 & 11.5 & 60.4 & 81.8 \\
$\mathrm{~N}_{2} \mathrm{~B}_{1}$ & 57.9 & 24.1 & 72.8 & 109.6 \\
$\mathrm{~N}_{3} \mathrm{~B}_{1}$ & 88.2 & 30.5 & 105.0 & 172.0 \\
$\mathrm{~N}_{4} \mathrm{~B}_{1}$ & 71.5 & 23.3 & 88.7 & 141.8 \\
$\mathrm{~N}_{0} \mathrm{~B}_{2}$ & 36.3 & 6.5 & 47.0 & 51.5 \\
$\mathrm{~N}_{1} \mathrm{~B}_{2}$ & 39.6 & 7.4 & 49.0 & 61.2 \\
$\mathrm{~N}_{2} \mathrm{~B}_{2}$ & 48.5 & 12.0 & 63.3 & 86.6 \\
$\mathrm{~N}_{3} \mathrm{~B}_{2}$ & 73.4 & 24.2 & 92.1 & 152.4 \\
$\mathrm{~N}_{4} \mathrm{~B}_{2}$ & 61.2 & 19.6 & 77.2 & 115.6 \\
$\mathrm{C} . \mathrm{D} @ 5 \%$ & 2.1 & 0.11 & 3.0 & 12.0 \\
\hline
\end{tabular}

control (Table 3, 4). The highest total nutrients uptake were recorded in combined treatments than individual application. Application of nitrogen and boron $\mathrm{N}_{3} \mathrm{~B}_{1}$ (225 kg N ha-1 and $1.5 \mathrm{~kg} \mathrm{~B} \mathrm{ha}^{-1}$ ) recorded the highest total nutrients uptake viz., $\mathrm{N}\left(88.2 \mathrm{~kg} \mathrm{ha}^{-1}\right), \mathrm{P}(30.5 \mathrm{~kg}$ $\left.\mathrm{ha}^{-1}\right), \mathrm{K}\left(105 \mathrm{~kg} \mathrm{ha}^{-1}\right)$ and $\mathrm{B}\left(172 \mathrm{~g} \mathrm{ha}^{-1}\right)$ which was significantly superior over other interactions. The increase in the nitrogen concentration might be attributed to better plant growth as boron helps in nitrogen absorption due to the synergistic relationship between nitrogen and boron(Abdel- Hady, 2007).
Concerning nitrogen levels, the highest total nutrients uptake viz., $\mathrm{N}\left(78.1 \mathrm{~kg} \mathrm{ha}^{-1}\right), \mathrm{P}\left(26.3 \mathrm{~kg} \mathrm{ha}^{-1}\right), \mathrm{K}(95.8 \mathrm{~kg}$ $\left.\mathrm{ha}^{-1}\right)$ and $\mathrm{B}\left(156.6 \mathrm{~g} \mathrm{ha}^{-1}\right)$ in $\mathrm{N}_{3}\left(225 \mathrm{~kg} \mathrm{ha}^{-1}\right)$, which was significantly superior over other $\mathrm{N}$ levels. The nutrients uptake increased up to $N_{3}$ and declined in $N_{4}(300 \mathrm{~kg} \mathrm{~N}$ $\mathrm{ha}^{-1}$ ). The lowest nutrients uptake was recorded in $\mathrm{N}_{0}$. Application of B increased the B uptake might be due to more vegetative and root growth, which releases root exudates resulting in increased boron availability in soil and finally, the uptake in plants (Debnath et al. 2015). The increase in the $B$ uptake may be ascribed to the 
increased availability of boron through the addition of borax, as reported by Rana et al. (2017).

Among the boron levels, the highest total nutrients uptake viz., $\mathrm{N}\left(60.5 \mathrm{~kg} \mathrm{ha}^{-1}\right), \mathrm{P}\left(17.8 \mathrm{~kg} \mathrm{ha}^{-1}\right), \mathrm{K}\left(74.9 \mathrm{~kg} \mathrm{ha}^{-1}\right)$ and $B\left(112.1 \mathrm{~g} \mathrm{ha}^{-1}\right)$ were registered in $B_{1}$, which was significantly superior over other boron levels. The nutrients uptake increased up to $B_{1}$ and declined in $B_{2}(3.0$ $\left.\mathrm{kg} \mathrm{ha}^{-1}\right)$. The lowest yield was recorded in $\mathrm{B}_{0}$. Increased $B$ uptake in grain and straw may be due to applied boron, which is efficiently translocated in the plant tissues for utilization (Shobharani and Latha, 2015) also opined the same in rice that boron has empowered the translocation efficiency of crops in submerged conditions. The increase in the $P$ uptake may be ascribed to the role of $B$ in the growth of root tips, whereas the membranebound ATPase activity increased due to higher levels of $B$ in the root. Similar findings were reported by Patel et al.(2018). Higher P uptake could be attributed to the well-developed root system improvement in vegetative growth and better availability of nutrients at the vital growth period. These findings corroborated with the study of Farooq et al. (2018), who reported that the application of boron improved the root growth, which facilitated the higher $\mathrm{P}$ uptake in rice. It has also been reported that the higher $\mathrm{K}$ uptake might be due to the synergistic relationship between the $\mathrm{K}$ and $\mathrm{B}$, favouring carbohydrate transport in rice (Ramesh and Rani, 2017)

\section{Conclusion}

Based on the findings of this study, it can be concluded that to attain higher productivity in rice ( $O$. sativa), the application of nitrogen and boron(225 kg ha-1 $+1.5 \mathrm{~kg}$ $\mathrm{ha}^{-1}$ ) may be recommended. The increase in the grain yield in combined treatments may be due to the general improvement in the nutritional state of the plant, particularly of the essential macronutrients and micronutrients. The B1(1.5 kg ha-1)over other B levels registered better results in nutrient-deficient soil. However, applying the medium level of nitrogen (225 kg ha-1) and boron $\left(1.5 \mathrm{~kg} \mathrm{ha}^{-1}\right)$ can be a better choice to attain the maximum yield of rice in sandy clay loam soils instead of applying low or higher levels of nitrogen and boron individually.

\section{ACKNOWLEDGEMENTS}

The authors thank Professor and Head, Department of Soil Science and Agricultural Chemistry, Faculty of Agriculture, Annamalai University for providing laboratory facilities for this research work.

\section{Conflict of interest}

The authors declare that they have no conflict of interest.

\section{REFERENCES}

1. Abbas, M., Zahida, T.M., Uddin, R. Sajjid, I. \& Akhlaq. (2013). Effect of zinc and boron fertilizers on some physiochemical attributes of five rice varieties grown in agroecosystem of Sindh, Pakistan. American Eurasian J. Agril. Environ. Sci., 13(4), 433-439.

2. Abdel-Hady, B.A. (2007). Effect of boron application on growth and nutrient uptake of rice plant irrigated with saline water. Res. J. Appl. Sci. 3(6), 431-436.

3. Ahamad, W. Niaz A., Kanwal S., Rahmatullah \& Rasheed M.K. (2009). Role of B in plant growth: A review. J. Agric. Res. 47(3): 329-338.

4. Amarendra Acharya, Neeraj Kumar, \& RameshGolait. (2020). Hand Book of Statistics on Indian States, Reserve Bank of India.

5. Agrinfobank (2019). Micronutrients and Macronutrients in Rice Production. https://agrinfobank.com.pk/ micronutrients-and-macronutrients-in-rice-production/.

6. Ankesh Chanchal, SatishKumar Singh, Abhik Patra \& Surendra Singh Jatav. (2020). Direct and residual effect of boron application on yield and nutrientscontent under ricewheat cropping system. Curr. J.Applied Sci. Tech. 39(2): 12-22.

7. Bandita Jena \& Nayak R.K. (2016). Enhancing nitrogen use efficiency and yield of rice with zinc and boron application in Inceptisolof Odisha. Annals of Plant and Soil Research. 18(1): 79-82.

8. Behera, M.P., Sahoo J., Mishra G.C., Mishra, G. and Mahapatra, A. (2018). Sulphur, zinc and boron nutrition on yield, economics and nutrient uptake in wet season rice (Oryza sativa L.) under rainfed ecosystem of Odisha India. International Journal of Chemical Studies. 6(4): 32963299.

9. Debnath, P., Pattanaaik, S.K., Sah D., Pandey A.K., DebashishSen, Chandra G. \& Ghosh. S.K. (2015). Response of boron and zinc fertilization to productivity of rice in Piedmont soil of Arunachal Pradesh. International Journal of Agriculture, Environment and Biotechnology. 8(4): 907914.

10. FAO. (2018). Rice market monitor. http://www.fao.or g/3/19243EN/i9243en.pdf.

11. Farooq, M., Rashid A., Nadeem F., Stuerz S., Asch F., Bell R.W. \& Siddique K. H. M. (2018). Boron nutrition of rice in different production systems. A review. Agron Sustain. Dev. 38, 25.

12. Gazala Nazir, Upinder Sharma \& Pardeep Kumar (2016). Boron - its importance in crop production status in Indian soils and crop responses to its application. International Journal of Advanced Research. 4(5), 654-660.

13. Jana, P.K., Ghatak, R., Sounde, G., Ghosh, R.K. \& Bandyopadhyay P. (2005). Effect of boron on yield content and uptake on NPK by transplanted rice at farmers field on red and laterite soils of west Bengal. J. Inter. Acad. 9, 341- 344 .

14. Jahan, M.S., Sultana, S. \& Ali M.Y. (2014). Effect of different $n$ levels on the yield performance of aromatic rice varieties. Bull. Inst. Trop. Agr. 37, 47-56.

15. Jiban Shrestha, Manoj Kandel, Subash Subedi \& KabitaKumari Shah. (2020). Role of nutrients in rice (Oryza sativa L.) : A review. Agrica, 9, 53-62. 
16. Juan Hirzel \& Francisco Rudriguez (2013). Increasing nitrogen rates in rice and its effect on plant nutrient composition and nitrogen apparent recovery. Chilean Journal of Agricultural Research,73(4), 385-390.

17. Manzoor, Z., Awan, T.H., Zahid, M.A. \& Faiz, F.A. (2006) Response of rice crop to different nitrogen levels. $J$. Anim. Plant Sci., 16, 52-55.

18. Muhammad Asif Shahzad \& Muhammad Maqsood (2015). Integrated nitrogen and boron fertilization improves the productivity and oil quality of sunflower grown in a calcareous soil. Turk. J. Field Crops. 20(2), 213-222.

19. Patel, S.K, Singh R.P., Saurabh Shrivastava, A.K. Pandey \& Chandel S.K.S. (2018). Effect of foliar application of boron at different stages of crop growth on nutrient utilization and yield of rice(Oryza sativa L.). Indian Journal Science Research, 9(2),1-6.

20. Ramesh R. \& Rani B. (2017). Effect of boron application through soil and foliar methods on the yield attributes and nutrient uptake of wetland rice. Agric. Update, 12, 301-304

21. Ramulu, C., Reddy, P.R.R. \& Narsaiah. (2020). Effect of nitrogen levels on yield and nutrient uptake of kharif rice (Oryza sativa L.) under different establishment methods.
Journal of Crop and Weed. 16(2):106-112.

22. Rana S.S., Sanjay K Sharma \& Sapna Kapoor. (2017). Effect of Nitrogen, zinc and boron on nutrient concentration at maximum tillering of wheat. Journal of Scientific and Technical Research, 1(7), 1895-1899.

23. Rashid A., Yasin M., Asraf M \& Mann R.A. (2004). Boron deficiency in calcareous soil reduces rice yield and grain quality. International Rice Research Notes, 29, 58-60.

24. Rehman, A., Farooq. M., Cheema Z.A. \& Wahid A. (2012). Seed priming with boron improves growth and yield of fine grain aromatic rice. Plant growth Regul., DOI: 10.1007/s10725-012-9706-2.

25. Salam, M.H., Ali F. and Anwar, M.P. \& Bhuiya M. S. (2004). Effect of level of $N$ and date of transplanting on the yield and yield attributes of transplanted Aman rice under SRI method. J. Bangladesh Agrl. Univ., 2(1), 31-36.

26. Shobharani \& Latha, A. (2015). Effect of secondary and micronutrients on nutrient uptake and yield of rice in Kolelands. International Journal of Current Research, 7(11), 22123-22126.

27. Singh, M.V. \& Goswami, V. (2014). Boron management in Indian Agriculture. Ind. J. Fert.,10(5), 104-115. 